\title{
PAPUA NEW GUINEA'S INDIGENOUS CULTURAL FESTIVALS: CULTURAL TRAGEDY OR TRIUMPH?
}

\author{
MICHELLE WHITFORD* AND ASHLEY DUNN $\dagger$ \\ *Department of Tourism, Sport and Hotel Management, Griffith University, \\ Nathan, Queensland, Australia \\ †Centre for Tourism, Leisure and Work, Southern Cross University, Coolangatta, Queensland, Australia
}

\begin{abstract}
Indigenous cultural festivals are increasingly being recognized for their contribution to the growth and vitality of communities around the globe. Such festivals invigorate the communication and celebration of indigenous culture, tradition, and rituals. Additionally, indigenous cultural festivals are often used as a draw card to attract tourists to a host destination and contribute to the development of the region. In Papua New Guinea (PNG), festivals have long been essential to community life and are fundamental in sharing and sustaining Indigenous culture. More recently, local communities and the PNG Government alike are recognizing that these festivals have the capacity to facilitate development of the country's embryonic tourism and event industry. The purpose of this qualitative research was to identify and examine cultural festivals in PNG, to develop a footprint of indigenous cultural festivals in PNG, and explore the extent to which tourism influences the cultural commodification of indigenous cultural festivals in PNG. Weaver and Lawton's cultural commodification model provided theoretical scaffolding for the development of the PNG Indigenous Festival Cultural Commodification Framework, which revealed that overall, cultural festivals in PNG are a relatively unspoiled resource. To date, tourism has had little influence on the festivals, which celebrate, among other things, PNG culture and traditions. However as tourism in PNG gains momentum, arguably a key issue will be the extent to which tourism development adopts the principles of sustainability and, concomitantly, avoids turning a triumph into a tragedy as a result of over commodification of PNG indigenous cultural festivals.
\end{abstract}

Key words: Indigenous cultural festivals; Commodification; Commercialization; Event tourism; Netnography; Papua New Guinea (PNG)

\section{Introduction}

Since the beginning of mankind, events have provided a means for people to relax, enjoy, and/or escape from their reality, often by embracing and celebrating a common interest. In contemporary society, events have not only demonstrated their capacity to sustain culturally significant celebrations of special occasions and historical events (Arcodia \& Robb, 2000) but they have also established their effectiveness as 
vehicles for the provision of entertainment and cultural expression and the development of social capital (Arcodia \& Whitford, 2006; Ziakas \& Costa, 2012). Not surprisingly then, Derrett (2000) claimed that events are an elixir that maintains community connection as they have the capacity to bind community ties and to facilitate constant rejuvenation of the community experience. Consequently, events continue to be an essential element of community life, contributing to the growth and vitality of host communities around the globe (Wang, 2009).

Festivals are an integral component of the event industry, facilitating societal development through community celebrations and support in encouraging cultural diversity (Wang, 2009). Indigenous communities in particular, including those in Papua New Guinea (PNG), have long realized the benefits of community celebration. Performances and colorful representations of heritage, life, traditions and ceremony have been, and continue to be, used by indigenous communities and individuals to, among other things, communicate spiritual beliefs and to practice rituals in a demonstration of cultural identity. It is within this realm that communities and individuals embrace their cultural purpose and find peace and sanctuary in which to share stories and experiences among themselves and with visitors. Additionally, cultural festivals, and indigenous cultural festivals in PNG in particular, are often used as a draw card to attract tourists to a region and, over time, some cultural events have become synonymous with the location in which they are held (i.e., hallmark festivals such as Edinburgh Festival and Oktoberfest). Thus, cultural festivals can and do play a significant role in regional development (Whitford, 2009a). In PNG, however, there appears to be a lack of leadership and strategic direction in relation to the development of indigenous cultural festivals. Arguably this has resulted from a lack of stable and/or coordinated government support (Abe \& Vincent, 2006), which has undoubtedly been exacerbated by PNG's history of unstable government. Not surprisingly then, until recently "policy development in the tourism (and event) industry has attracted little focus and policy implementation has been uncoordinated" (Abe \& Vincent, 2006, p. 21). Moreover, the development of cultural festivals in particular, has enjoyed little to no government support (Abe \& Vincent, 2006) and to date there has been a dearth of academic research investigating cultural festivals within the context of tourism. The majority of research pertaining to PNG has, for example, focused on PNG politics (Reilly, 1999), totemism (Biersack, 1999), anthropology (Morauta, 1979), ecology (Diamond, 1986; Frith \& Beehler, 1998), linguistics (Bruce, 1984), cultural variables of sheep raising (Grossman, 1984), the social process (Leach, 2002), and sustainable tourism of the Kokoda Track (Wearing, Wearing, \& McDonald, 2010). The very limited research undertaken on PNG festivals is for the most part from a philanthropic and anthropological perspective. Hence, to date, little to no effort has been made to gain a more comprehensive understanding (both theoretically and/or practically) of cultural festivals in PNG within the context of tourism and events. Therefore, there is a real need for research pertaining to PNG cultural festivals, to be undertaken from a tourism and event planning perspective, to not only strengthen and broaden the theoretical scope of event studies literature but also to better inform and facilitate a sustainable approach to the planning and development of cultural festivals in PNG within the context of tourism.

The purpose of this qualitative research was to identify and examine cultural festivals in PNG, to develop a footprint of indigenous cultural festivals in PNG, and explore the extent to which tourism influences the cultural commodification of indigenous cultural festivals in PNG. To achieve this, the context of this article is set by providing a brief overview of PNG and the PNG Tourism Master Plan (Abe \& Vincent, 2006) in particular. Next, the article provides a theoretical overview of indigenous festivals and tourism before outlining the qualitative methodology utilized in the study. The results and discussion of analysis of indigenous cultural festivals in PNG follow. The final sections of the article discuss the implications pertaining to the utilization of indigenous cultural festivals as a vehicle to develop PNG's tourism and event industry and then outline potential pathways for future research.

\section{Papua New Guinea}

PNG, marketed as the land of the unexpected (Fitzpatrick, 2011), is one of the least visited countries in the world and a last frontier for international travelers (W. Shaw, 2010). Situated 160 km north 
of Australia, PNG is made up of more than 600 islands. There are four regions (i.e., Papua, Momase, Highlands, and New Guinea Islands) made up of 22 provinces including the National Capital District. The harsh and rugged landscape of PNG is home to the largest area of intact rainforest outside of the Amazon, steep mountain ranges, turbulent rivers, untouched beaches, unique flora and fauna, and active volcanoes (Manning \& O'Fairncheallaigh, 2000). PNG is also home to over 5 million people constituting more than 1,000 different indigenous cultural communities. It is considered to be one of the most heterogeneous populations in the world, predominately living outside urban districts in rural areas, and differentiated by their own language, customs, and traditions (Papua New Guinea Tourism Promotions Authority [PNG TPA], n.d.). There are in excess of 860 indigenous languages (tok ples) accounting for a third of the world's indigenous tongues (PNG TPA, n.d.). The indigenous communities of PNG embrace the varying cultures through visual expressions (i.e., festivals of art, dance, singing, music, self-decoration, and craftsmanship), which are all integral to the ongoing way of life in PNG (Morauta, 1979). It is the rich and diverse cultural festivals, combined with a diverse population and some of the world's most unique flora, fauna, and landscapes, that provide PNG with a unique selling proposition as an attractive adventure-driven tourism and event destination (Abe \& Vincent, 2006).

\section{Tourism in PNG}

There are significant opportunities in PNG for the development of what can arguably be termed an "embryonic" tourism and event industry (Abe \& Vincent, 2006). For instance, PNG is arguably in the exploration stage of development (Butler, 1980) as it is a relatively unexplored destination in which visitor numbers are small, and access, facilities, and local knowledge are limited (Abe \& Vincent, 2006). Additionally, PNG faces many challenges pertaining to law and order (Dinnen, 2001) and visitors' safety in some parts of PNG can be, and often is, problematic (Abe \& Vincent, 2006). Travel warnings about PNG can be found on numerous government websites around the globe (e.g., Australia's Smart Traveler website) and travel bloggers have voiced concerns and cautions about safety and security in PNG (Aragina, 2002; Ricardo, 2005). Yet the safety, or lack thereof, for visitors to PNG is not the only identifiable issue associated with tourism and/ or attending indigenous cultural festivals in PNG. Generally, there are relatively poor and unreliable support services (i.e., police, ambulance), various health risks (i.e., malaria HIV/AIDS), quite limited resources and infrastructure to support tourism and events, limited and unreliable access to technology (i.e., internet), and expensive internal travel costs with some associated safety concerns (Abe \& Vincent, 2006). Moreover, information for tourists traveling to and within PNG is limited and not easily accessible for travelers, and Australia's Smart Traveler website repeatedly makes mention of the need to exercise caution while traveling in PNG, to maintain awareness of personal safety, particularly at night, and to continuously monitor the local media for warnings on new safety and security risks (SmartTraveler, 2012).

In general, tourism development in PNG has failed to keep pace with the rest of the world (Abe \& Vincent, 2006). In the South Pacific for example, "tourism (and events) represents a major opportunity for small island nations to increase their economic base, expand foreign exchange earnings and enhance the standard of living for their people" (Abe \& Vincent, 2006, p. 22). Yet according to the PNG Tourism Master Plan (Abe \& Vincent, 2006),

PNGs' share of the (South Pacific) regional market is very small, at only 5 percent of total arrivals, and less than 2 percent of the holiday market. This indicates the low level of development of this market compared to other neighbouring countries, as well as the importance of the business market to PNG. (p. 23)

According to the PNG Tourism Master Plan (Abe \& Vincent, 2006), this can be attributed to a lack of support for the tourism industry by the PNG Government over the last 20 years. For instance, there is a lack of adequate infrastructure to support tourism in PNG. This can be evidenced at the Mt. Hagen Cultural Show where limited accommodation facilities are all booked out in advance so any additional participants arriving at the festival cannot find accommodation because of lack of infrastructure. Additionally, internal travel and 
accommodation in PNG is expensive because of a high demand from mining and logging industries (Abe \& Vincent, 2006).

Although there still appears to be a lack of government policy both at the national and provincial level specifically for guiding and sustaining cultural festivals and tourism, in more recent years there has been growing interest from the PNG Government to facilitate the growth of the tourism and event industry in PNG. In 2006, the Independent Consumer and Competition Commission (ICCC) and the PNG TPA formulated the Tourism Master Plan 2007-2017 with the aim of sustaining the future development of the PNG tourism industry (Abe \& Vincent, 2006). The priority of the plan is to spearhead destination marketing (among other things) by replacing the existing Tourism Promotion Authority with a specific industry -driven body called "Tourism PNG." The vision of the Master Plan is that by 2017, PNG tourism will be a growing, sustainable industry that is globally recognized for its unique and memorable experiences, provision of employment and investment opportunities, protection and enhancement of the environment and cultural heritage, strong partnerships and collaborations with stakeholders, and distribution of benefits throughout PNG to improve both rural and urban community lifestyles (Abe \& Vincent, 2006). The goal of the PNG Tourism Master Plan is to increase the overall economic value of tourism and to maximize sustainable tourism growth in PNG (Abe \& Vincent, 2006).

\section{Indigenous Cultural Festivals}

Festivals are manifestations of culture and thus are an effective vehicle with which to realize the goals of the PNG Tourism Master Plan. Festivals have the capacity to diversify local economies, improve local networks, and encourage cooperation, while engendering inclusion, celebration, and community (Gibson, Waitt, Walmsley, \& Connell, 2010). Not only do cultural festivals facilitate the realization of such benefits for the community, but they also provide an outlet for individuals to regain control of their lives, away from the outside pressures of Western culture (Slater, 2010). According to Salamone (2000) and Ziakas and Costa (2012), festivals generate a feeling of goodwill and community or a spirit of "communitas" and "are one of the few consistently positive spaces for Indigenous communities to forge and assert a more constructive view of themselves" (Phipps, 2010, p. 217). In fact, in Cape York, Australia, community celebrations and cultural ceremonies are considered highly effective vehicles for improving Aboriginal health and wellbeing (Slater, 2010). Indeed, in Australia there are well over 100 indigenous festivals varying in size and purpose held annually (Phipps \& Slater, 2010) and increasingly, health, education, employment, and other well-being services are recognizing the power of cultural festivals in creating a supportive environment to work with indigenous communities in their own terrain towards building better futures (Phipps \& Slater, 2010). Therefore,

\begin{abstract}
Festivals are important to Indigenous communities for their contribution to Indigenous community wellbeing, resilience and capacity. They increase individual and community self-esteem and cultural confidence, develop local leadership, social, cultural and economic initiatives, open creative spaces of individual and collective opportunity, and provide a focus for governments and other service providers to better engage community needs and aspirations. (p. 86)
\end{abstract}

\section{Indigenous Cultural Festivals and Tourism}

There is little argument that festivals hold untapped potential for supporting community development goals including meeting any unmet demands for domestic and international tourism experiences (Phipps \& Slater, 2010). For instance, in Norway, the Samis' Ridu Ridu is an international indigenous festival that attracts delegates and participants from all over the world who are seeking opportunities to experience various aspects of indigenous culture (Johansen, 2010). These motivations, among others, are indicative of tourists' growing interest in the values, knowledge, and traditions of indigenous cultures. Consequently, indigenous festivals are a growing tourism phenomenon as the demand for indigenous tourism experiences, around the globe, steadily increases alongside the number of indigenous peoples who are becoming an integral part of the tourism industry (Zeppel, 2006).

Importantly, however, several critical questions have been raised about the impact of (event) tourism on indigenous peoples (Johnston, 2006). Smith 
(2003) argued that the impacts of tourism, and arguably event tourism, to indigenous societies are more or less comparable to impacts of the modern and postmodern world in general. Moreover, according to Henry (2008), a significant risk to cultural indigenous festivals is the commercialization of history and culture, which is often manifested in staged performances choreographed and presented to attract the tourist dollar (see MacCannell, 1973). Productions of cultural performances designed for tourist consumption are becoming staged experiences that are synchronized with tourist wants, which ultimately destroy authenticity (Cohen, 1988; Weaver \& Lawton, 2006). Thus, presenting cultural heritage for tourism purposes raises issues including authenticity versus marketability and conservation versus commoditization (McKercher \& du Cros, 2002). That is, "the process where a cultural or natural asset is made accessible to tourists as consumable products, and the cultural assets also gain economic value” (Johansen, 2010, p. 5). Communities not only face the pressures of commodification, commercialization, and unauthentic representation of their culture, but also the challenge of connecting and communicating with visitors. Haydon (2007) warned that a significant hurdle for indigenous people is language/communication barriers and the often confronting nature of face-to-face interactions, made all the more difficult through mass tourism, which erodes the potential for personal experiences between the host and visitor. Not surprisingly then, Johansen (2010) claimed that festivals, marketplaces, and other cultural attractions involve commodification and commercialization of culture and heritage even though it is becoming more common to appreciate tourism in cultural heritage management (Boniface, 1998).

In the process of adapting and taking advantage of tourism's benefits, ardent attempts at commercialization have the ability to damage community traditions and sociocultural values (Arcodia \& Whitford, 2006). Moreover, an underlying threat resulting from commercialism is the homogenization of different cultures, which extinguishes individuality through massification of culture, also known as globalization (Gil, 2009). By mainstreaming culture, one can run the risk of misuse and misappropriation of indigenous culture (KTA, 2008). Macdonnell (1997) therefore insisted that in attuning such spectacles for the international market, we must be mindful that "we don't erode the reason why we create art in the first place" (p. 1). Consequently, it is vitally important that the purpose of a cultural festival is honored and respected and that the festival is developed and staged according to the needs and wants of a host community. Arguably, when this occurs, as a result of mutual understanding and respect, both the host and participants are provided with an opportunity to experience creativity, expression, connection, and celebration (Taylor, 2007). Furthermore, cultural festivals, such as those in PNG, have the capacity to engender in the host and in participants, a sense of place and community through connections, support, empowerment, belonging, and participation (Derrett, 2003).

\section{Research Methods}

The purpose of this research was to develop a footprint of PNG indigenous cultural festivals in order to explore the extent to which tourism influences the development of cultural festivals. To achieve this, the study adopted a qualitative research design employing thematic analysis to identify and then examine indigenous cultural festivals in PNG. To identify the footprint of indigenous cultural festivals in PNG, a database of purposively selected festivals was constructed according to the following criteria:

1. The festival had to be staged and operated in PNG;

2. The festival had to have an indigenous cultural focus/theme (i.e., traditional and/or contemporary and/or commercialized indigenous PNG culture); and

3. The festival had to have either a tourism and/or community cultural purpose.

The festivals were sourced via a keyword Google search that included visiting PNG Government, tourism, travel, and provincial websites to locate online cultural festival calendars. Fifty-four festivals satisfied the selection criteria and were cataloged in an Excel spreadsheet according to festival name, location, province, duration, event description, organization, and website reference. Next, the festivals were identified by province (see Fig. 1) and then grouped into PNG's four regions (i.e., Highlands, 


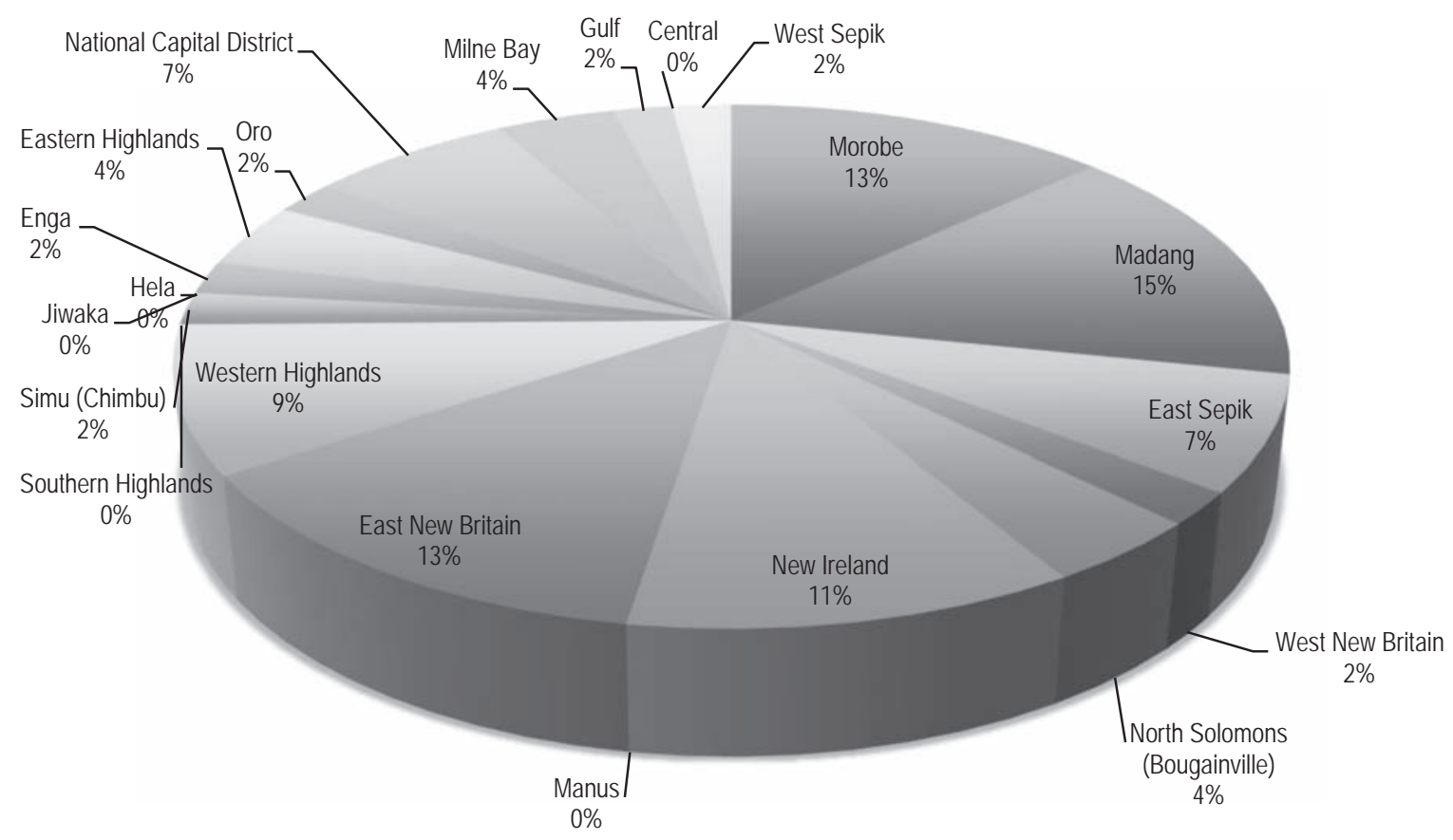

Figure 1. PNG indigenous cultural festivals by province.

New Guinea Islands, Momase, and Papua) and the weighted dispersion of the festivals was calculated (Highlands, 14.81\%; New Guinea Islands, 35.19\%; Momase, 29.63\%; Papua, 20.37\%).

It is important to note here that to ensure a comprehensive search was undertaken to identify all PNG cultural festivals, three PNG tourism and event experts validated the number of identified festivals. Although only one festival was added as a result of this process, the results of the study should be viewed as indicative, given the propensity for, and likelihood of, small (undocumented) community festivals occurring in the multitude of villages throughout PNG.

To gain a deeper understanding of tourism's influence on the festivals, the qualitative method of netnography was employed. Netnography was conceptualized by Kozinets $(1997,1998)$ as an adaptation of ethnography to study the meanings, symbolism, attitudes, perceptions, and imagery of online consumer communication (Beckmann \& Langer, 2005). In society today, there is a growing interest among travelers to express and share their experiences with others via internet communication mediums, such as online social networking forums. As a result, the internet is considered an effective means in which to gather rich information about tourists and tourist destinations for social research purposes because of the unlimited access to knowledge contributed by people worldwide (Govers \& Go, 2005; Hine, 2008; Markham, 2004; Safdar, Jumani, \& Nazar, 2011).

Compared with traditional qualitative techniques such as interviews, netnography has unique advantages: it is more expeditious, less cumbersome, and more natural, unobtrusive, and cost-effective (e.g., as data emerge already transcribed, without coercion, and travel costs are eliminated), and it also arguably generates more honest, candid, and personal accounts of lived experiences through reviews posted voluntarily in the blogosphere where participants can assume pseudonymous identities (Dwivedi, 2009; Kozinets, 1998, 2002; Mkono, 2011; Morgan, 2008; Nancarrow, Pallister, \& Brace, 2001). In relation to this study, netnography proved to be a more appropriate and useful 
approach for accessing and gathering data about PNG cultural festivals over more traditional qualitative methods (Langer, 2003; Pires, Stanton, \& Cheek, 2003). While disadvantages associated with employing netnography are recognized (see Bartl, Hück, \& Ruppert, 2009; Dholakia \& Zhang, 2004; Kozinets, 1998, 2002, 2006) they were offset by the method's ability to gather rich data from diverse participants about diverse perceptions without the risk of researcher-observer influence (Mateos \& Durand, 2012).

Information about the PNG cultural festivals was sourced from online tourism and travel blog websites to gain more nuanced insights from stakeholders (i.e., residents, travelers, industry professionals) about various aspects of the festivals including issues pertaining to commercialization and authenticity. Data collection took place between October and December 2011 and included current blog entry information. Originally located via a Google search of each festival's name, the online blogs/websites were only included if they had dedicated forums to travel, tourism, and PNG (e.g., Lonely Planet and Virtual Tourist). All data written within the blogs that focused on one or more of the PNG cultural festivals were included for analysis. Not surprisingly, the larger festivals resulted in more blog postings, whereas the smaller community festivals had little to no blog postings.

Thematic analysis was conducted on the blog postings to identify and examine emerging themes according to the Weaver and Lawton (2006) model (Braun \& Clarke, 2006; Daly, Kellehear, \& Gliksman, 1997). The blog postings were reviewed twice before a process of manual coding was done to first generate codes and then themes for analysis (Fereday \& Muir-Cochrane, 2006). Independent analysis of the blog postings was undertaken, underpinned by Weaver and Lawton's (2006) cultural commodification model, before comparisons and interpretations of findings (Bartl et al., 2009) were developed into an Indigenous Festival Cultural Commodification Framework (Fig. 3).

In recent years, there has been growing concerns within the literature about tourism development and associated issues of commercialization, authenticity, and exploitation of culture (e.g., Chambers, 1997; Cohen, 1988; Gibson et al., 2010; Henry, 2008; Ryan, 1997; Whitford, 2009b). In particular, Doxey's
(1976) "Irridex" and the Product Life Cycle (see Kotler, Bowen, \& Makens, 2006) are both concerned with the maturation of tourism development; however, neither specifically focuses on the significance of culture in the process. Weaver and Lawton (2006), however, developed a four-phase model of cultural commodification, which was a useful framework to categorize the festivals. That is, some festivals may offer an authentically rich experience performed by locals for locals (Phase 1), whereas others may be a cultural commodity that is wholly commercialized to meet tourist expectations at the expense of cultural authenticity (Phase 4) (Weaver \& Lawton, 2006). Employing Weaver and Lawton (2006) as a theoretical lens, the framework was developed (see Table 1) based upon four latent codes (i.e., commodification, cultural authenticity, sociocultural impacts, and tourism development) that were identified from the literature and corresponded to Weaver and Lawton's (2006) key themes.

Importantly, the same three experts who verified the festival database were asked to provide feedback on this article. This was to ensure cultural appropriateness and semantic validity (Krippendorf, 1980) of the following Anglo-Celtic interpretation, analysis, and discussion of results was achieved. The feedback from the PNG tourism and event experts has been included in the article and referenced as personal communication. Due to the exploratory nature of the study, the results of the research that reflect the perceived influence of tourism on cultural festivals at the time this study was conducted, are limited in scope. Given the limitations of the study, including language barriers and cultural differences, the results cannot be extrapolated to the wider population.

\section{The Footprint of Indigenous Cultural Festivals in Papua New Guinea}

Throughout history, the people of PNG have practiced rituals and traditions predominantly in the form of festivals, which have, among other things, reunited and/or strengthened communities. The results of this research suggest that contemporary PNG has a strong and vibrant cultural festival footprint, evidenced by an array of diverse and culturally rich festivals located and staged throughout the country (see Fig. 2). 
Table 1

PNG Indigenous Cultural Festivals Analysis Framework

\begin{tabular}{|c|c|c|}
\hline Theory & Latent Codes & Code Criteria \\
\hline \multirow[t]{4}{*}{$\begin{array}{l}\text { Weaver and Lawton’s (2006) } \\
\text { Cultural Commodification } \\
\text { Process }\end{array}$} & 1. Commodification & $\begin{array}{l}\text { 1. Transforming a community's culture into a commodity for the } \\
\text { "tourist dollar” (Chambers, 1997; Cohen, 1988; Gibson et al., } \\
\text { 2010; Henry, 2008; Johansen, 2010; Ryan, 1997; Whitford, 2009b) } \\
\text { 2. Social capital and commodification (Arcodia \& Whitford, 2006) } \\
\text { 3. Conservation versus commodification (McKercher \& du Cros, 2002) } \\
\text { 4. Locals begin to emulate the behavior of tourists - the Demonstration } \\
\text { Effect (G. Shaw \& Williams, 2002) }\end{array}$ \\
\hline & $\begin{array}{l}\text { 2. Cultural } \\
\text { authenticity }\end{array}$ & $\begin{array}{l}\text { 1. Cultural traditions are exploited for tourism whereby performances, } \\
\text { etc., are staged to meet tourists' expectations resulting in inauthen- } \\
\text { tic representations of culture (Chambers, 1997; Cohen, 1988; Gil, } \\
\text { 2009; Henry, 2008; Phipps, 2010; Ryan, 1997; Whitford, 2009b) } \\
\text { 2. Frontstage/backstage model of authenticity (MacCannell, 1973) }\end{array}$ \\
\hline & $\begin{array}{l}\text { 3. Sociocultural } \\
\text { impacts }\end{array}$ & $\begin{array}{l}\text { 1. Positive and negative sociocultural impacts upon a community } \\
\text { associated with event and tourism development (Allen, O’Toole, } \\
\text { McDonnell, \& Harris, 2008; Chambers, 1997; Jackson, 2008; } \\
\text { Sims \& D’Mello, 2005; Whitford, 2009b) } \\
\text { 2. Focusing on political-economic rather than sociocultural goals } \\
\text { (Grossman, 1984) } \\
\text { 3. Doxey’s (1976) Irritation Index } \\
\text { 4. Social Exchange Theory (Ap, 1992) }\end{array}$ \\
\hline & $\begin{array}{l}\text { 4. Tourism } \\
\text { development }\end{array}$ & $\begin{array}{l}\text { 1. Developing a community to better take advantage of the benefits } \\
\text { of tourism, potentially resulting in both positive and negative } \\
\text { impacts (Butler, 1980; Weaver \& Lawton, 2010) }\end{array}$ \\
\hline
\end{tabular}

The various locations of the PNG cultural festivals are distinctive as they occur in one of the world's most diverse biological environments, rich in flora and fauna and steeped in culturally rich customs, heritage, history, and indigenous peoples (Lahui, 2008; Nicholls, 2004). The majority (64.82\%) of indigenous PNG cultural festivals are staged in the Momase and New Guinea Islands regions, which have a rich culture and are diverse in artistic traditions (National Cultural Commission, 1999). According to a local PNG tourism expert (personal communication, 2012), expression of PNG culture takes different forms and has different requirements. For example, some PNG cultural displays require minimal preparation time whereas others, especially in the Highlands, require more preparation time and are expensive to showcase. This may also depend on the needs of the people. In the Highlands, for instance, people have vast areas of land, which they can use for gardening and their other recreational and commercial needs and Highlanders are also viewed as being assertive in pursuit of satisfying their needs. On the coast, however, and especially on the islands, where resources may be scarce and the inhabitants are less assertive, tourism and cultural events in particular, are seen as a way to sustain communities and their livelihood, hence providing a possible reason why there is a higher proportion of cultural events taking place on the coast.

Regardless of where the festivals are staged, they are recognized as vehicles for not only exhibiting the rich and vibrant culture of PNG but also for the maintenance of heritage, traditions, and the PNG identity (Bougainville Tourism Office, 2010; Jasons, 2011). For example, PNGs celebrate the following festivals throughout the provinces of PNG: sacred animals (The Crocodile Festival, East Sepik Province), ancestral spirits of the famous Asaro Mud Men (Rabaul Mask Festival, East New Britain Province), the journeys of the Motuan people (Hiri Moale Festival, National Capital District), cultural tribal gatherings (Goroka Cultural Show, Eastern Highlands), and the significant crafts of the canoe and Kundu drums (National Canoe and Kundu Festival, Milne Bay Province). Additionally, there are the ceremonial displays of self-decoration and tribal wear (Mount Hagen Cultural Show, Western Highlands Province), which according to Sillitoe (1988), are by far "the most striking artistic mode 


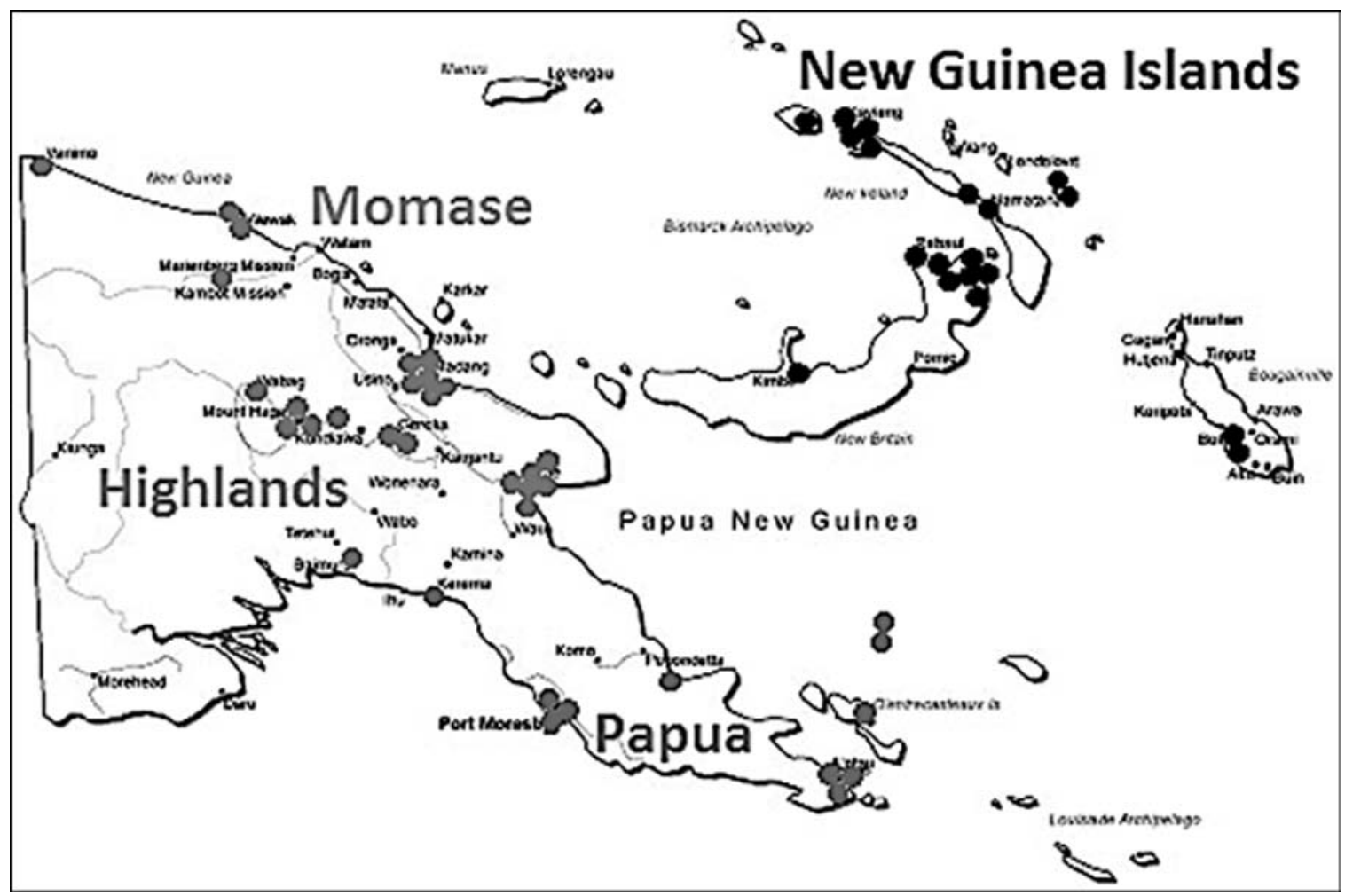

Figure 2. Indigenous cultural festival footprint of PNG (source: adapted from Map Resources, 2012).

in which people living (in PNG) express themselves” (p. 298). Not surprisingly then, the linguistically, culturally, and artistically diverse regions of PNG provide visitors with opportunities for “astonishing” travel experiences (Ellingson, 2010). Hence, indigenous cultural festivals are arguably a strength that PNG's tourism and event industry can draw upon in order to realize, among other things, the vision of the PNG Tourism Master Plan, which includes maximizing sustainable tourism growth for PNG (Abe \& Vincent, 2006).

\section{PNG Indigenous Cultural Festivals and Cultural Commodification}

Although sustainable tourism growth has the capacity to be potentially beneficial to the development of PNG, the question remains: To what extent will such tourism growth influence the cultural commodification of indigenous cultural festivals in PNG? To date, tourism in PNG is in a nascent stage of development yet analysis of the PNG indigenous cultural festival footprint indicates that although many small festivals continue to be community focused and display little to no influence of commodification, some of the slightly larger festivals are, to varying degrees, beginning to show the signs of cultural commodification, primarily it would seem, to accommodate tourists attending the festivals. Accordingly, the indigenous cultural festivals of PNG are situated in Phases 1 and 2 of the Indigenous Festival Cultural Commodification Framework (see Fig. 3).

The four-phased framework (Fig. 3), which was informed by Weaver and Lawton (2006), draws attention to the transformation of a community's culture from an authentically rich experience performed by locals for locals (Phases 1 and 2), to a cultural commodity that is wholly commercialized to meet tourist expectations at the expense of authenticity (Phases 3 and 4). The smaller festivals of PNG such as the Ambunti Crocodile Festival, Bargam 


\section{Phase 1 - Authentic culture is shared with minimal tourist numbers with a focus on cultural preservation and sharing whereto urists may be given genuin e artefacts}

Ambunti Orocodile Festiva [East Sepik)

Bargam Show(Madang)

Buka Mona Festiva ( North

Solomons - Bougainville)

Chor al Festival District Show [East New Britain]

DukDukFestival (East New Britain]

Enga Cultural Show(Enga)

Gulf Mask Festival (Gulf)

Ind Cultural Show(Morobe)

Kalam Dultural Festiva (Madang)

Kangal Festival (Madang)

Kavieng Distrid (Malagan)

Dultural Show(Newrel and)

Ko ko mo Cultural Show (Madang)

Kokopo District Cutural

Show(East NewBritain)

Kono Wokisok Fest ival ( $\mathrm{New}$ reland)

Kortu/Te mbin Shark Calling (Newirel and

Madang Festival (Madang)

Malagan Festival (New reland)

Malmalang Festiva (New reland)

Middle Sepikfestival (East Sepik)

MIne Bay Rice Festiva ( $M$ ine Bay)

Miri Canoeand Kul a Festiva (MIne Bay)

Namatanai Mask Festival (New Ireland)

Namatanai Miri Mask

Festival (New reland)

National Garamut \& Mack

Festivad (East Sepik)

Sel Kambang (West Sepik)

Tanga Yam Festival (New reland)

Tawur Cultural Show(West New Britain )

Tofa Cance Festival (New reland)

Tufi Cultural Festiva (Oro) Tumbuna Mask Festival (East New Britzin ]

Tu mbuna Sing S no (Western Highlands)

Ugwabwena Yam Festival ( $M$ Ine Bay)
Phase 2 - Increase in tourist visitation

resulting in decline of cultural novelty with small fees charged for attendance and purchase of artefacts

Ahi Cultural Festival (Morobe)

Cameron High School

Cultural Show(Milne Bay)

Divine Word Uhiversity

Cultural Show(Madang)

Gogodala Canoe Festival

(Westem Hghlands)

Goroka Bilum Festiva

(Eastern Highlands)

Goroka Show(Eastern Highlands)

Hin Moale Festival (National Capital District]

Milne Bay Music Festival (Milne Bay)

Morobe Agri-Dultural Show (Morobe)

Morobe Yam Festiva (Morobe)

Mourt Hagen Show

(Westem Hghlands)

National Arts \& Crots

Exhibition (National Capital District)

National Canoe \& Kundu Festival (MIne Bay) National Mas kFestival (East New Britain]

New reland Cultural Day

(Naicnal Capital District)

Pajya Festival (Western Highlands]

Reeds Festival (North

Solomons - Bougainville)

Waghi Cultural Show( Jiwka)

Warwagra Cutural Show (East New Eritain)

Warwagra Mask Festival [East New Eritain)

Wasin National High School Cultura Day (Morcoe) Zu mi m Pottery Show (Morobe)

\section{Phase 3}

\section{Beginning \\ of \\ Phase 4}

significant

change

where

culture is

altered to

appeal to

the mass

tourists,

authenticity

starts to

fade and

become

contrived,

and high

prices are

charged for

admission

and

purchase of

cheap

souvenis
Complete

commodifi-

cation and

moderni-

sation of

culture

brought

about by

tourism

developmen

$t$ resulting

in a loss of

originality

and culturad

integrity

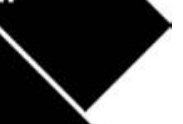


Show, Paiya Festival, and Tumbuna SingSing are situated in Phase 1 of the framework (Fig. 3) where little to no cultural commodification has occurred. According to bloggers these (Phase 1) festivals are intimate and traditional festivals held within small villages. Their primary purpose is community celebration and they typically focus on cultural preservation and sharing (Greenwood, 1989). Moreover, there are minimal tourists attending the festivals and locals invariably give tourists genuine artefacts to take home. Bloggers said that the Bargam Show and the Kalam Cultural Show are seen as "bona fide" local festivals, staged by the local people for the local people and not for tourists. Moreover, at the Kalam Cultural Show, the Kalam people still practice their traditional dances and rituals of pig killing and nose piercing within their villages. Concomitantly, however, there are signs that the Kalam people are beginning to make minor changes to the festival program to accommodate a small number of tourists attending the festival. For instance, according to a local PNG:

They kill, then butcher, then cook the pigs right
in front of you. They wear traditional dress while
doing it just for the tourists' sake though. Then for
dinner if you are lucky they give you some of the
pig. The nose piercing of the male initiation takes
place away from tourist eyes inside a temporarily
constructed house without any doors or windows
(they are sealed in there until the deed is done).
The tourists are allowed to be present when the
boys break out of the house to complete the initia-
tion. (personal communication, 2012)

It appears then, that tourism is beginning to influence the program of the Kalam Cultural Show and therefore if tourist numbers grow, it may not be too far in the future that the festival is situated in Phase 2 of the framework.

Festivals situated in Phase 2 of the framework often experience a small increase in tourist visitation resulting in a decline of cultural novelty where small fees may be charged for attendance and for the purchase of artifacts. For instance, larger festivals in PNG including the Goroka Show, Mount Hagen Show, the National Canoe and Kundu Festival, and the Kokopo National Mask Festival are situated in Phase 2 as they are more publicized and thus attended by more tourists (mainly from Europe and the US) (Abe \& Vincent, 2006). Interestingly, bloggers noted that Goroka, Mt Hagen, and the Kokopo National Mask Festival charge tourists more expensive entrance fees than the entrance fees locals have to pay (Cleland, 2011; Preece, 2009).

Increasing numbers of tourists at these festivals generate competing needs between tourists and locals. Tourists may want to see a 15 -minute cultural presentation compared to a local PNG, who is concerned about completing a ritual, which could take 25 minutes (personal communication, 2012). Additionally, it was noted that at the Kokopo National Mask Festival, local dance groups were watched (and often interrupted) by Western visitors who took pride of place on a VIP stage that displayed advertising for Coca Cola. Dancers often posed for the tourists' cameras, impacting on the authentic, traditional rituals of groups getting ready for their performances (Ellingson, 2010). Bloggers also commented on noticeable changes in the making of some traditional items, such as Bilum's (i.e., carry bags), traditional clothes, costumes, and decorations. Store bought string and modern materials including metallic paints, tinsel, musical instruments, and plastic Virgin Mary statues most commonly associated with the Western culture are replacing traditional elements used in the creation of art (i.e., plant materials) (Cheng, 2005; Dave \& Rosie, 2011; Robert, 2009). Importantly, the use of synthetic materials is often due to the growing scarcity of natural materials as Western development increasingly impinges upon villages and the surrounding environment (personal communication, 2012).

Tourists' safety is also becoming an increasing priority at some of the larger, more publicized festivals. Tourists at the Mount Hagen Show felt hands reach into their pockets on numerous occasions searching for valuables, while other attendees have had personal items stolen (e.g., cameras) and some have been held up by raskols (i.e., roving urban gang members; see Dinnen, 2001) with machetes (Cheng, 2005; Hughes, 2011). In response to safety concerns, travelers noted that crowd control at one festival was accomplished with a barbed wire fence, positioned between the tourists/visitors and the parading tribes (Preece, 2009). Consequently, although these festivals strive to retain much of their authentic traditions, various aspects of the festivals are being altered to accommodate tourism. 
For example, a local PNG tourism expert commented that:

\begin{abstract}
a considerable factor is nowadays hosting cultural events requires massive resources such as money which event organising committees do not have. So there is a change of emphasis - traditionally such events were held strictly based on traditional customs and obligations, whereas now a number of organisations participate through sponsorships so the needs have changed. (personal communication, 2012)
\end{abstract}

Tourists have also noticed that the Goroka and Mount Hagen Shows are similar to an Australian country agricultural (commercial) show. According to a local PNG:

the two festivals were started in 1950s and 60s by Australian administrators who based the festivals on the model of Australian agricultural shows. While they are not authentic tribal festivals per se, but rather a showcase of various authentic tribal singsings from all over PNG, the locals take full ownership over the festival. It is like ersatz tribal warfare, tribes dance instead of fighting. They measure success by how many visitors are watching. (personal communication, 2012)

Thus, it would appear reasonable to suggest that to varying degrees, the gradual growing influence of tourism in PNG is contributing to cultural commodification across the PNG indigenous cultural festival footprint. The commodification of PNG indigenous cultural festivals is arguably a multipronged sword. On the one hand, some visitors are apparently not yet deterred by a more commercial approach to PNG cultural festivals as several of the larger festivals are known to attract upwards of 800 tourists (Malum-Nalu, 2011). Although the presence of visitors, expatriates, and their camera equipment was recognized as intrusive and rude by some travelers, for the most part travelers still felt that the atmosphere of the festivals was very authentic (Dave \& Rosie, 2011; Moser \& Moser, 2006; Preece, 2009). On the other hand, bloggers also said that other visitors and locals alike believed increased tourist numbers detract from the authenticity of the experience and that smaller festivals may lose their intimate feel as they become more publicized and attended by tourists. Moreover, travelers and indeed some PNGs are concerned that as a result of the introduction of colonial practices and the impact of Western culture upon the economy, PNG's traditions and diverse culture are undergoing transformation. Boyd (1985) noticed this change in the Eastern Highlands province where the transition from traditional pig slaughter and distribution ceremonies (once considered the most elaborate and sacred rituals), to commercial dance festivals called Singsing Bisnis, has been sparked by the "revolution of commercialization." Similarly, Martin (2008) also discussed the culturally rich Kokopo Mask Festival, which is organized by the East New Britain Tourism Authority who apparently envisage the festival not only as a vehicle to "preserve and protect culture in PNG" (p. 97) but also as a potential tourist attraction. According to Martin (2008), there is tension among the locals regarding the purpose of the festival as some locals believe that the festival damages rather than preserves kastom (Tok Pisin: meaning custom) as a result of commercialization from tourism, and as such will be considered a business and not kastom if the main motivation is wealth over community cohesion. Indeed, local PNGs have voiced strong views that their unique cultural heritage will disappear through progressive generations and that it is highly important that the culture remains everlasting. Moreover, some locals are concerned that the PNG Government is blind to the consequences PNGs will face if appropriate action is not taken post haste (Kimbirye, 2005; NGALT-K, 2005). According to Ellingson (2010), PNG's culture and environment must not be separated during the development of the country otherwise PNGs will become spectators to their surroundings where peoples' identities and meaning of life will be lost.

Consequently, as tourism in PNG gains momentum, arguably a key issue will be the extent to which tourism development adopts the principles of sustainability (World Commission on Environment and Development, 1987) and concomitantly avoids turning a triumph into a tragedy as a result of overcommodification of PNG indigenous cultural festivals. PNG indigenous cultural festivals should arguably strive to:

remind people of the importance of their culture and their identity ... (and) keep a unique diversity of cultures alive which too easily might get 
completely lost in the westernization and modernisation Papua New Guinea is striving for. (Moser \& Moser, 2006)

\section{Implications and Conclusions: Triumph or Tragedy?}

Herein lies the conundrum for PNG's indigenous communities as they are increasingly faced with the task of juggling PNG heritage, customs, culture, and traditions with economic and social restructuring associated with the neoliberal influences of globalization (Dredge \& Whitford, 2011). Such influences typically dominate local interests and give cause for concern in relation to the public interest, issues of governance, and the role government and stakeholders play in the planning and sustainable management of indigenous cultural festivals in PNG. Surely uninformed, inappropriate, unplanned management of tourism in general, and indigenous cultural festivals in particular, has the potential to damage the natural and sociocultural environment (Choi \& Sirakaya, 2006) and, arguably, facilitate escalating episodes of commodification of indigenous PNG culture and lifestyle and impact on the degree to which PNG indigenous cultural festivals retain the essence of PNG culture. In turn, this will surely impact upon the capacity of indigenous cultural festivals to triumph as effective, appropriate, and sustainable vehicles for the development of PNG's tourism and event industry.

The challenge, and arguably potential tragedy, will occur if economic priorities suffocate sociocultural aspirations in PNG. It has been long established that governments around the globe, invariably underpinned by neoliberal ideology (Broomhill, 2001; Dredge et al., 2010; Larner, 2000; Whitford, 2009a), have been utilizing event tourism as an effective vehicle to facilitate economic benefits in particular. According to Richards (2007), the role of culture in contemporary society is like a double -edged sword. On the one hand, culture can support society's collective memory and identification, whereas, on the other hand, it is a source of economic development and a platform used for political gain. Not surprisingly, the PNG Tourism Master Plan focuses on economic development (Wood, Robinson, \& Thomas, 2006) and consistently highlights the economic benefits that can be derived from tourism and, to a lesser extent, the tourism spin-offs from staging (business) events in PNG. According to the PNG Tourism Master Plan (Abe \& Vincent, 2006), the tourism industry in PNG is currently underpinned by the business travel market, accounting for almost $70 \%$ of all visitors to the country. Thus, the Plan notes the need to: "Establish a Special Events Unit within the new 'Tourism PNG' and develop and implement a marketing strategy for the MICE (Meetings, Incentives, Conventions and Exhibitions tourists) market” (Abe \& Vincent, 2006, p. 47).

Interestingly, although the Plan does also identify cultural festivals as a strength of the PNG tourism sector, it fails to note either the opportunities or, importantly, the threats associated with future development of this sector (Abe \& Vincent, 2006). Moreover, according to a PNG tourism expert, the PNG TPA and National Cultural Commission (NCC), which control the purse strings for festival planning and coordination, "fail to acknowledge diverse cultural and environmental differences when deciding or 'forcing' the promotion of different types of festivals onto different locations" (personal communication, 2012). Arguably, this perpetuates an ad hoc, unsustainable approach to the development of festivals in PNG. Such an approach by government bodies is both alarming and somewhat naive, given the potentially diverse array of benefits that can be derived from staging cultural festivals. For instance, they have the capacity to improve the destination image (Tasci \& Gartner, 2007) and overall marketability of PNG as a tourist destination while providing much needed socioeconomic opportunities for a developing nation. Moreover, festivals can provide an avenue not only for the development of social capital throughout PNG (Arcodia \& Whitford, 2006; Guetzkow, 2002; Sharpley \& Stone, 2011; Ziakas \& Costa, 2012) but they can also promote and communicate much needed health and environmental education for locals and visitors (Papua New Guinea Government, 2010; Phipps \& Slater, 2010; World Health Organization, 2010). Furthermore, festivals are a means by which indigenous PNGs can rejuvenate and develop spiritual and cultural beliefs and thus facilitate the sustainable development of indigenous culture, heritage, and the environment. Consequently, there are strong sociocultural arguments for growing and developing sustainable indigenous cultural festivals in PNG. Yet the extent to which 
the PNG Tourism Master Plan (i.e., the PNG Government) recognizes, appreciates, and/or plans for developing the full potential of indigenous cultural festivals appears negligible.

The need for sustainable government initiatives and a coordinated approach in relation to the development of cultural festivals is even more crucial when considered within the context of the PNG indigenous cultural festival footprint. Given the number and diversity of cultural festivals occurring throughout the country, alongside a growing awareness of utilizing tourism as a development tool, it would seem reasonable to suggest that it will not be long before local PNG organizations and communities become more and more involved in staging cultural festivals, and in some instances rival festivals, to gain market share of a globally lucrative event industry (Getz, 2007). Indeed, this is:

happening already. Since the Kalam Festival is becoming a money maker for the Simbai people, other tribes are noticing and trying to follow suit. There is a village north of Madang interested in hosting an annual canoe race in this sort of manner. (personal communication, 2012)

The adoption of a more commercial approach to the development of indigenous cultural festivals in PNG, without proactive, sustainable, and coordinated planning and management, is likely to result in cultural festivals becoming "absorbed into the expansive stock of 'products' that tourists desire" (Picard \& Robinson, 2006, p. 2). The risk of course is commodification of the festivals and the potential loss of the essence of indigenous PNG culture and the raison d'être of the festivals (Weaver \& Lawton, 2006). Indeed, increased influences of globalization, commercialization, and commodification will arguably dilute indigenous PNG culture and diminish opportunities for indigenous PNG peoples to honor, respect, and preserve their life, culture, history, spiritual beliefs, traditions, and customs via community celebration.

Collectively then, there is a need to ensure the development of a sustainable tourism and event industry in PNG to minimize the commodification of festivals while protecting and preserving the integrity of indigenous cultural festivals throughout the country (Musgrave \& Raj, 2009; O’Sullivan \& Jackson, 2002). To avoid serendipitous outcomes because of a lack of strategic planning (Chalip, 2006), Whitford and Ruhanen (2010) advocated the need for government policies "to develop a framework which draws upon Indigenous diversity and in a consistent, collaborative, co-ordinated and integrated manner, provide the mechanisms to facilitate long term sustainable Indigenous cultural festivals” (p. 25). Moreover, the PNG government needs to actively "preserve, protect, promote and develop PNG's art and culture" in accordance with the initiative of the PNG NCC, which was sanctioned by a Parliamentary Act in 1994 (Lahui, 2008, p. 3). Organizers of PNG cultural festivals should be cognizant of the role of authenticity as a significant element of cultural attractions, bearing in mind that definitions of authenticity or what is regarded as authentic vary from group to group or from individual to individual (Mehmetoglu \& Olsen, 2003; Smith \& Forest, 2006). For instance, according to a local PNG tourism expert, changes in culture and tradition do not necessarily translate into commercialization and loss of authenticity.

Not all Papua New Guineans live in villages now and not all have access to the traditional materials. Those in towns will go to the trade store and buy their red face paint there instead of finding a 'bam' tree and extracting the red seeds. The tinsel in the store looks pretty and it goes well with the bird of paradise feathers, so why not?

If the culture was becoming commercialised for attracting tourists, I would argue that you wouldn't see things like ... modern additions to traditional dress. It too obviously breaks the illusion that this is an authentic tribal dance. Instead, you see these things and realise that it is a progression of their culture. The dance isn't a voyeuristic, tourist time machine of their first contact with Europeans. It is something for themselves in modern times. (personal communication, 2012)

Nevertheless, to avoid what McKercher and du Cros (2002) refer to as a "cultural tragedy," indigenous PNGs will ideally be cognizant of the influence tourism can and does have on the development of indigenous cultural festivals. Increased awareness of the influence tourism can have on festivals will mean that PNGs will be better equipped to avoid or at the very least manage the commodification of festivals and continue the daily fight required to maintain and retain a way of life in order to triumph 
over external forces and the omnipresent influence of Western culture (Phipps \& Slater, 2010).

\section{The Way Forward}

To facilitate future sustainable development of indigenous cultural festivals in PNG, further empirical research is required to build a deeper understanding of the role of festivals and event tourism in indigenous communities by working collaboratively with both communities and government. For instance, there is a need to explore how indigenous PNGs perceive authenticity in relation to cultural festivals. A deeper understanding of what constitutes authenticity from the perspective of indigenous PNGs will provide insight into the extent to which cultural festivals can withstand commercialization and commodification and thus assist in sustainably developing, planning, and managing future indigenous cultural festivals in PNG. Additionally, future research should not only investigate the implementation and outcomes of policies such as the PNG Tourism Master Plan but also the experiences of the people who developed the policies and, in particular, the views and experiences of indigenous PNGs involved in tourism and cultural festivals. Moreover, there is need for a greater understanding of the role of governance in the planning and development of indigenous cultural festivals to ensure governance is simply not rhetoric that empowers corporate stakeholders over and above grass roots indigenous communities. Therefore, there is a need to commit to a quest for greater understanding of indigenous PNG's perspectives if cultural festivals are to progress in an appropriate and sustainable manner. Such research would augment the results of this study, in addition to building a more nuanced, deeper understanding of the planning, development, and management of indigenous cultural festivals as it relates to indigenous peoples and indigenous cultural festival development around the globe.

\section{Acknowledgments}

The authors would like to thank Mr. John Imbal and Ms. Erigere Signin from the Papua New Guinea Alliance of Civil Societies Organisation, and Mr. Jonathon Bludhorn from Madang Visitors and Cultural Bureau Papua New Guinea for their valued contribution to this research.

\section{References}

Abe, T., \& Vincent, P. (2006). Papua New Guinea tourism sector review and master plan - 2007-2017: Growing PNG tourism as a sustainable industry. Retrieved August 14, 2011, from http://www.tpa.papuanewguinea. travel/PicsHotel/PNGTA/Brochure/TPAFactsheets/ Tourism\%20Master\%20Plan.pdf

Allen, J., O’Toole, W., McDonnell, I., \& Harris, R. (2008). Festival and special event management (4th ed.). Milton, Australia: John Wiley \& Sons.

Ap, J. (1992). Residents' perceptions on tourism impacts. Annals of Tourism Research, 19(4), 665-690.

Aragina. (2002, August 25). Crime: Papua New Guinea has a high crime rate. Retrieved from http://members.virtual tourist.com $/ \mathrm{m} / \mathrm{p} / \mathrm{m} / 3216 \mathrm{e} /$

Arcodia, C., \& Robb, A. (2000). A future for event management: A taxonomy of event management terms. Paper presented at the Events Beyond 2000: Setting the Agenda, Sydney: Australian Centre for Event Management School of Leisure, Sport and Tourism, University of Technology.

Arcodia, C., \& Whitford, M. (2006). Festival attendance and the development of social capital. Journal of Convention and Event Tourism, 8(2), 1-18.

Bartl, M., Hück, S., \& Ruppert, S. (2009). Netnography research: Community insights in the cosmetic industry. Paper presented at the ESOMAR Consumer Insights, Dubai, United Arab Emirates.

Beckmann, S., \& Langer, R. (2005). Netnography: Rich insights from online research. Insights, 14(6).

Biersack, A. (1999). The Mount Kare Python and his gold: Totemism and ecology in the Papua New Guinea Highlands. American Anthropologist, 101(1), 68-87.

Boniface, P. (1998). Tourism culture. Annals of Tourism Research, 25(3), 746-749.

Bougainville Tourism Office. (2010, August 11). Welcome to the 2010 Digicel Bougainville Mona Festival - 12-14 August 2010. Retrieved from http://pngtourism.blogspot. com/2010/08/welcome-to-2010-digicel-bougainville_11. html

Boyd, D. J. (1985). The commercialisation of ritual in the Eastern Highlands of Papua New Guinea. Man, 20(2), 325-340.

Braun, V., \& Clarke, V. (2006). Using thematic analysis in psychology. Qualitative Research in Psychology, 3(2), 77-101.

Broomhill, R. (2001). Neoliberal globalism and the local state: A regulation approach. Journal of Australian Political Economy, 48(1), 115-140.

Bruce, L. (1984). The Alamblak language of Papua New Guinea (East Sepik) [Pacific Linguistics C113]. Canberra: The Australian National University.

Butler, R. (1980). The concept of a tourist area life cycle of evolution: Implications for management of resources. Canadian Geographer, 24(1), 5-12. 
Chalip, L. (2006). Towards social leverage of sport events. Journal of Sport \& Tourism, 11(2), 109-127.

Chambers, E. (1997). Tourism and culture: An applied perspective. Albany, NY: State University of New York Press.

Cheng, E. (2005, August 7). Mt. Hagen Cultural Show 2005. Retrieved from http://echeng.com/travel/papuanew guinea/mthagenshow/

Choi, H., \& Sirakaya, E. (2006). Sustainability indicators for managing community tourism. Tourism Management, 2(6), 1274-1289.

Cleland, B. (2011, February 19). First Goroka show 1956. Retrieved from http://bobcleland.wordpress.com/2011/ 02/19/first-goroka-show-1956/

Cohen, E. (1988). Authenticity and commoditization in tourism. Annals of Tourism Research, 15(3), 371-386.

Daly, J., Kellehear, A., \& Gliksman, M. (1997). The public health researcher: A methodological approach. Melbourne, Australia: Oxford University Press.

Dave, \& Rosie. (2011, July 17). Kokopo Mask Festival. Retrieved from http://daveandrosie.files.wordpress.com/ 2011/07/kokopo-mask-festival.pdf

Derrett, R. (2000). Can festivals brand community cultural development and cultural tourism simultaneously. Paper presented at the Events Beyond 2000: Setting the Agenda, Sydney: Australian Centre for Event Management School of Leisure, Sport and Tourism, University of Technology.

Derrett, R. (2003). Making sense of how festivals demonstrate a community's sense of place. Event Management, 8(1), 49-58.

Dholakia, N., \& Zhang, D. (2004). Online qualitative research in the age of e-commerce: Data sources and approaches. Forum Qualitative Sozialforschung/Forum: Qualitative Social Research, 5(2), Art. 29.

Diamond, J. (1986). Biology of birds of paradise and bowerbirds. Annual Review of Ecology and Systematics, 17(1), 17-37.

Dinnen, S. (2001). Law and order in weak state. Crime and politics in Papua New Guinea (Pacific Islands monograph). Hawaii: University of Hawaii Press.

Doxey, G. (1976). When enough's enough, the natives are restless in old Niagara. Heritage Canada, 2(2), 26-27.

Dredge, D., Ford, E., Lamont, M., Phi, G., Whitford, M., \& Wynn-Moylan, P. (2010). Event governance: Background to the World Rally Championship, Northern Rivers, NSW. Centre for Tourism, Leisure and Work: Southern Cross University, Tweed Heads, New South Wales.

Dredge, D., \& Whitford, M. (2011). Event tourism governance and the public sphere. Journal of Sustainable Tourism, 19(4/5), 479-499.

Dwivedi, M. (2009). Online destination image of India: A consumer based perspective. International Journal of Contemporary Hospitality, 21(2), 226-232.

Ellingson, M. (2010, December 31). Alotau hosted a cultural extravaganza. Retrieved from http://islandmeri. wordpress.com/2010/12/31/alotau-hosted-a-culturalextravaganza/
Fereday, J., \& Muir-Cochrane, E. (2006). Demonstrating rigor using thematic analysis: A hybrid approach of inductive and deductive coding and theme development. International Journal of Qualitative Methods, 5(1), 80-92.

Fitzpatrick, P. (2011, November 23). Good reading and writing in Papua New Guinea. Retrieved from http://asopa. typepad.com/asopa_people/2011/11/good-reading-andwriting-in-papua-new-guinea.html

Frith, C., \& Beehler, B. (1998). The birds of paradise. Oxford: Oxford University Press.

Getz, D. (2007). Event studies: Theory, research and policy for planned events. Oxford, UK: Elsevier ButterworthHeinemann.

Gibson, C., Waitt, G., Walmsley, J., \& Connell, J. (2010). Cultural festivals and economic development in nonmetropolitan Australia. Journal of Planning Education and Research, 29(3), 280-293.

Gil, A. (2009). Cultural identity and globalisation. Paper presented at the Culture, Politics, Ethics: Interdisciplinary Reflections, Salzburg, Austria.

Govers, R., \& Go, F. (2005). Projected destination image online: Website content analysis of pictures and text. Information Technology \& Tourism, 7(2), 73-89.

Greenwood, D. (1989). Culture by the pound: An anthropological perspective on tourism as cultural commoditization. In V. Smith (Ed.), Hosts and guests: The anthropology of tourism (pp. 171-186). Philadelphia, PA: University of Pennsylvania Press.

Grossman, L. S. (1984). Sheep, coffee prices, and ceremonial exchange in Papua New Guinea. Geographical Review, 74(3), 315-330.

Guetzkow, J. (2002). How the arts impact communities: An introduction to the literature on arts impact studies. Paper presented at the Taking the Measure of Culture Conference, Princeton University, New Jersey. Retrieved from, http://www.princeton.edu/ artspol/workpap/WP20\%20\%20Guetzkow.pdf

Haydon, J. (2007). Indigenous community festivals-top end: An evaluation using Encore event evaluation kit. Retrieved August 14, 2011, from http://www.crctourism. com.au/WMS/Upload/Resources/bookshop/Haydon_ IndigFestivals.pdf

Henry, R. (2008). Engaging with history by performing tradition: The poetic politics of Indigenous Australian festivals. In J. Kapferer (Ed.), The state and the arts: Articulating power and subversion (pp. 52-69). New York: Berghahn Books.

Hine, C. (2008). Internet research as emergent practice. In S. Nagy Hesse-Biber \& P. Leavy (Eds.), Handbook of emergent methods. New York: The Guilford Press.

Hughes, K. (2011, August 31). Aug 13-15 Hagen Show! Retrieved from http://www.travelblog.org/Oceania/PapuaNew-Guinea/Western-Highlands/Mount-Hagen/blog638350.html

Jackson, L. A. (2008). Residents' perceptions of the impacts of special event tourism. Journal of Place Management and Development, 1(3), 240-255. 
Jasons. (2011). Festivals in Papua New Guinea. Retrieved October 12, 2011, from http://www.jasons.com/papuanew-guinea/festivals-in-papua-new-guinea

Johansen, T. E. (2010). Ethnic revitalisation, cultural growth and commodification. Indigenous festivals and events in Troms County in Norway. Paper presented at the Global Events Congress IV: Festivals \& Events Research, Leeds Metropolitan University, United Kingdom.

Johnston, A. (2006). Is the sacred for sale? London: Earthscan.

Kimbirye. (2005, June 3). Waghi Cultural Show_-Highlands Post. Retrieved from http://www.voy.com/10582/2/2541. html

Kotler, P., Bowen, T., \& Makens, J. (2006). Marketing for hospitality and tourism (4th ed.). Upper Saddle River, NJ: Pearson Education Inc.

Kozinets, R. (1997). "I want to believe”: A netnography of the x-philes' subculture of consumption. Advances in Consumer Research, 24(1), 470-475.

Kozinets, R. (1998). On netnography: Initial reflections on consumer investigations of cyberculture. Advances in Consumer Research, 25(1), 366-371.

Kozinets, R. (2002). The field behind the screen: Using netnography for marketing research in online communities. Journal of Marketing Research, 39(1), 61-72.

Kozinets, R. (2006). Click to connect: Netnography and tribal advertising. Journal of Advertising Research, 46(3), 279-288.

Krippendorf, K. (1980). Content analysis: An introduction to its methodology. Beverly Hills, CA: Sage.

KTA. (2008). Discussion paper: Socio-cultural impacts of Aboriginal cultural industries. Retrieved August 12, 2011, from http://kta.on.ca/pdf/SocioCulturalmpacts.pdf

Lahui, H. (2008). National Cultural Commission: State of safeguarding PNG's intangible cultural heritage. Paper presented at the Inter-Departmental Meeting on the Convention for the Safeguarding of the Intangible Cultural Heritage Crown Plaza Hotel, Port Moresby, Papua New Guinea.

Langer, R. (2003). SKIN TWO: (Un)-covering the Skin in Fetish Carnival. Paper presented at the European Association for Consumer Research Conference (EACR). Dublin, Ireland.

Larner, W. (2000). Neo-liberalism: Policy, ideology, governmentality. Studies in Political Economy, 63(Autumn), 5-25.

Leach, J. (2002). Drum and voice: Aesthetics and social process on the Rai Coast of Papua New Guinea. Journal of the Royal Anthropological Institute, 8(4), 713-734.

MacCannell, D. (1973). Staged authenticity: Arrangements of social space in tourist settings. American Journal of Sociology, 79(3), 589-603.

Macdonnell, J. (1997). All the world's a stage. 24 Hours, ABC Publications.

Malum-Nalu. (2011, July 28). Papua New Guinea's greatest show on again! Retrieved from http://malumnalu. blogspot.com/2011/07/papua-new-guineas-greatestshow-on.html
Manning, H. J., \& O’Fairncheallaigh, C. (2000). Papua New Guinea. American Journal of Economics \& Sociology, 59(5), 385-398.

Map Resources. (2012). Papua New Guinea-vector map. Retrieved February 8, 2012, from http://www.mapresources.com/papua-new-guinea-black-and-whiteillustrator-digital-vector-road-map-png-xx-714503.html

Markham, A. (2004). Internet communication as a tool for qualitative research. In D. Silverman (Ed.), Qualitative research: Theory, method and practice (2nd ed.). London: Sage Publications.

Martin, K. (2008). The work of tourism and the fight for a new economy: The case of the Papua New Guinea Mask Festival. Tourism, Culture \& Communication, 8(2), 97-107.

Mateos, P., \& Durand, J. (2012). Residence vs. ancestry in acquisition of Spanish citizenship: A 'netnography' approach. Migraciones Internacionales, 6(4), 9-46.

McKercher, B., \& du Cros, H. (2002). Cultural tourism: The partnership between tourism and cultural heritage management. Binghamton, NY: The Haworth Hospitality Press.

Mehmetoglu, M., \& Olsen, K. (2003). Talking authenticity: What kind of experiences do solitary travellers in the Norwegian Lofoten Islands regard as authentic? Tourism, Culture \& Communication, 4(3), 137-152.

Mkono, M. (2011). The othering of food in touristic eatertainment: A netnography. Tourist Studies, 11(3), 253-270.

Morauta, L. (1979). Indigenous anthropology in Papua New Guinea. Current Anthropology, 20(3), 561-576.

Morgan, M. (2008). What makes a good festival? Understanding the event experience. Event Management, 12(2), 81-93.

Moser, B., \& Moser, N. (2006, October 17). Who put all that paint into my face. Retrieved January 10, 2012, from http://www.travelblog.org/Oceania/Papua-New-Guinea/ blog-91166.html

Musgrave, J., \& Raj, R. (2009). Introduction to a conceptual framework for sustainable events. In R. Raj \& J. Musgrave (Eds.), Event management and sustainability. Oxfordshire, UK: CAB International.

Nancarrow, C., Pallister, J., \& Brace, I. (2001). A new research medium, new research populations and seven deadly sins for Internet researchers. Qualitative Market Research, 14(3), 136-149.

National Cultural Commission. (1999). 5th PNG Tumbuan Mask Festival. In Y. Toyoda (Ed.), Art and national identity: A case of Papua New Guinea. Japan Consortium Area Studies Research Reports

NGALT-K. (2005, June 8). Waghi Cultural Show-Highlands Post. Retrieved from http://www.voy.com/10582/2/2541. html

Nicholls, S. (2004). The priority environmental concerns of Papua New Guinea. IWP-Pacific Technical Report (International Waters Project) No. 1. Apia, Samoa: South Pacific Regional Environment Programme.

O’Sullivan, D., \& Jackson, M. (2002). Festival tourism: A contributor to sustainable local economic development? Journal of Sustainable Tourism, 10(4), 325-342. 
Papua New Guinea Government. (2010). Transforming our health system towards Health Vision 2050: National Health Plan 2011-2020. Volume 1 Policies and Strategies. Waigani NCD, PNG: Strategic Policy Division of the National Department of Health.

Papua New Guinea Tourism Promotions Authority. (n.d.). About PNG TPA. Retrieved September 21, 2011, from http://www.tpa.papuanewguinea.travel/

Phipps, P. (2010). Performances of power: Indigenous cultural festivals as globally engaged cultural strategy. Alternatives: Global, Local, Political, 35(3), 217-240.

Phipps, P., \& Slater, L. (2010). Indigenous cultural festivals: Evaluating impact on community health and wellbeing. Melbourne, Australia: Globalism Research Centre, Royal Melbourne Institute of Technology.

Picard, D., \& Robinson, M. (2006). Festivals, tourism and social change. Clevedon, UK: Channel View Publications.

Pires, G., Stanton, J., \& Cheek, B. (2003). Identifying and reaching an ethnic market: Methodological issues. Qualitative Market Research, 6(4), 244-235.

Preece, M. (2009, August 23). Mt Hagen Cultural Show. Retrieved from http://mattinpng.com/2009/08/23/mthagen-cultural-show/

Reilly, B. (1999). Party politics in Papua New Guinea: A deviant case? Public Affairs, 72(2), 225-246.

Ricardo. (2005, June 19). Welcome to the jungle. Retrieved from http://members.virtualtourist.com/m/9c39f/c78/

Richards, G. (Ed.). (2007). Cultural tourism. Global and local perspectives. Binghamton, NY: Haworth Press.

Robert. (2009, September 15). Goroka Bilum Festival 2009. Retrieved from http://www.trupela.com/2009/09/15/ goroka-bilum-festival-2009/

Ryan, C. (1997). Carving and tourism: A Maori perspective. Annals of Tourism Research, 24(4), 898-918.

Safdar, M., Jumani, N., \& Nazar, N. (2011). Assessing the effective use of internet technology in teacher training. Paper presented at the 3rd SAICON: International Conference on Management, Business Ethics and Economics (ICMBEE), Pearl-Continental Hotel Lahore, Pakistan.

Salamone, F. (2000). Society, culture, leisure and play: An anthropological reference. Lanham, MD: University Press of America.

Sharpley, R., \& Stone, P. (2011). Socio-cultural impacts of events: meanings, authorized transgression, and social capital. In S. Page \& J. Connell (Eds.), The Routledge handbook of events. London: Routledge.

Shaw, G., \& Williams, A. (2002). Critical issues in tourism: A geographical perspective (2nd ed.). London: Blackwell.

Shaw, W. (2010). Serendipitous coffee experiences in Papua New Guinea. In L. Jolliffee (Ed.), Coffee, culture, destinations and tourism (pp. 134-158). Bristol, UK: Channel View Publications.

Sillitoe, P. (1988). From head-dresses to head-messages: The art of self-decoration in the Highlands of Papua New Guinea. Man, 23(2), 298-318.

Sims, W. J., \& D’Mello, L. (2005). Event denizens and the sports tourist: Pre-event perceptions of the social impacts of a major event. Paper presented at The Impacts of Events Conference UTS Australian Centre for Event Management.

Slater, L. (2010). 'Calling our spirits home’: Indigenous cultural festivals and the making of a good life. Cultural Studies Review, 16(1), 143-154.

SmartTraveler. (2012). Papua New Guinea travel advice. Retrieved February 13, 2012, from http://www.smartraveller. gov.au/zw-cgi/view/Advice/Papua_New_Guinea

Smith, M. (2003). Issues in cultural tourism studies. London and New York: Routledge.

Smith, M., \& Forest, K. (2006). Enhancing vitality or compromising integrity? Festivals, tourism and the complexities of performing culture. In D. Picard \& M. Robinson (Eds.), Festivals, tourism and social change. Cleveland, Buffalo and Toronto: Channel View Publications.

Tasci, A., \& Gartner, W. (2007). Destination image and its functional relationships. Journal of Travel Research, 45(4), 413-425.

Taylor, A. (2007). Creative, expressive, connected remembered. Retrieved September 14, 2011, from http://www. artsjournal.com/artfulmanager/main/creative_expressive_ connected.php

Wang, Y. (2009). The impact of festivals and events on city image: A case analysis of Ningbo International Fashion Festival. M.A. degree in cultural economics and cultural entrepreneurship Thesis, Erasmus University, Rotterdam. Retrieved from http://oaithesis.eur.nl/ir/repub/asset/6490/ Wang\%20Ying\%20master\%20thesis.pdf

Wearing, S., Wearing, M., \& McDonald, M. (2010). Understanding local power and interactional processes in sustainable tourism: Exploring village-tour operator relations on the Kokoda Track, Papua New Guinea. Journal of Sustainable Tourism, 18, 61-76.

Weaver, D., \& Lawton, L. (2006). Tourism management (3rd ed.). Milton, Queensland: John Wiley \& Sons.

Weaver, D., \& Lawton, L. (2010). Tourism management (4th ed.). Milton, Queensland: John Wiley \& Sons.

Whitford, M. (2009a). A framework for the development of event public policy: Facilitating regional development. Tourism Management, 30(5), 674-682.

Whitford, M. (2009b). Oaxaca's indigenous Guelaguetza festival: Not all that glistens is gold. Event Management, 12(3-4), 143-161.

Whitford, M., \& Ruhanen, L. (2010). Australian indigenous tourism policy: Practically sustainable? Journal of Sustainable Tourism, 18(4), 475-496.

Wood, E., Robinson, L., \& Thomas, R. (2006). Evaluating the social impacts of community and local government events: A practical overview of research methods and measurement tools. In S. Fleming \& F. Jordan (Eds.), Events and festivals: Education, impacts and experiences. Eastbourne, UK: Leisure Studies Association.

World Commission on Environment and Development. (1987). Our common future. Oxford/London: Oxford University Press.

World Health Organization. (2010). Country cooperation strategy - At a glance. Retrieved February 15, 2012, from 
http://www.who.int/countryfocus/cooperation_strategy/ ccsbrief_png_en.pdf

Zeppel, H. (2006). Indigenous ecotourism: Sustainable development and management. Oxfordshire, UK: CAB International.
Ziakas, V., \& Costa, C. (2012). The show must go on: Event dramaturgy as consolidation of community. Journal of Policy Research in Tourism, Leisure and Events, 4(1), 28-47. 